\title{
SPACE FUNCTION AND SHAPE OF BALAI ADAT IN KOTO SENTAJO TRADITIONAL VILLAGE
}

\author{
Sepli Yandri ${ }^{*}$, Suzanna Ratih Sari ${ }^{2}$, Agung Budi Sardjono ${ }^{2}$ \\ $\left.{ }^{1}\right)$ Postgraduate Department of Architecture, Universitas Diponegoro, Indonesia \\ $\left.{ }^{2}\right)$ Department of Architecture, Faculty of Engineering, Universitas Diponegoro, Indonesia \\ *Corresponding e-mail: sepli.yandri09@gmail.com
}

\section{Article info:}

Received: 4-3-2019, Revised: 10-3-2019, Accepted: 11-3-2019

\begin{abstract}
Indonesia is known for its tribe diversity in various regions. One area that still has traditional villages is the Koto Sentajo area. The lives of people in the Koto Sentajo village still implement traditional values inherited from generation to generation. As a village, it certainly has a shelter in the form of a house and a worship facility in the form of a mosque. In the Koto Sentajo traditional village, there are traditional buildings called Balai adat. The existence of a Balai adat is inseparable from the traditional values that developed in the community. Balai adat plays an important role in a traditional village as a gathering place and deliberation to find solutions to problems that occur in the village. The purpose of this study was to find out the role of Balai adat in Koto Sentajo village and to conclude the spatial function and the shape of the building that became the identity of the traditional settlements in Kuantan Singingi. The method of descriptive analysis is employed, as a way of delivering in-depth descriptions on how the functions of space and the forms contained in the traditional hall in Koto Sentajo.
\end{abstract}

Keywords: Balai Adat, Koto Sentajo, Kuantan Singingi.

\section{Introduction}

Koto Sentajo is one of the traditional villages located in Kuantan Singingi district. According to Hamidy, 2000, koto is a village that function as the center of government and fortress. Koto is built on a higher place or on top of the hills on the edge of the river. In the Koto village, there are still traditional buildings such as traditional houses, traditional mosques, and the traditional hall is called Balai Adat.

Traditional settlements are often represented as places that still hold customary and cultural values related to beliefs or religions that are specific or unique to a particular society rooted in certain places which are also beyond historical determination (Sasongko, 2005), as a traditional village, the lives of people in the Koto Sentajo village still adhere to traditional values inherited from generation to generation. Customary values also influence the buildings found in the Koto Sentajo village. According to Rapoport (1969), socio-cultural factors are determinants of architectural manifestations, because there is a value system in them that will guide humans in seeing and understanding the world around them.

According to Yulianto Sumalyo (1993), vernacular is a local language, in the term architecture to refer to forms that apply cultural elements, the environment including local climate, expressed in the physical architectural form (layout plan, structure, parts details, ornaments, etc.). While the definition of the vernacular architecture according to Paul Oliver in the Encyclopedia of Vernacular Architecture of the World is made up of people's houses and other buildings, which are related to their environmental context and available resources that are owned or built, using traditional technology. All forms of vernacular architecture are built to meet specific needs to accommodate the values, economics, and ways of life of a developing culture. 
As a vernacular building found in the Koto village, the balai adat has an important role in traditional life in the Koto Sentajo. Balai adat as one of the traditional symbols in the Koto village serves as a gathering place and deliberation. Balai adat is used to solve problems that occur in a village.

\section{Methods}

The method used in this writing is a study of analysis description, by describing and analysing the object of research. Descriptive analysis used in this study is the descriptive analysis that is explorative in nature, which aims at describing the state of something or the status of a phenomenon. This research focused on the function of space and the form of Balai adat in the Koto Sentajo. Data were obtained through in-depth interviews. Informants, local residents, and traditional leaders are those who provided information. In this research, interviews proved to be the best method to maximize the opportunity to obtain field data.

\section{Result \& Discussion}

\subsection{Overview}

Koto Sentajo is a village located in Kuantan Singingi District, Riau Province. The atmosphere of the Koto Sentajo village is still traditional. There are still many traditional buildings like traditional houses. Traditional mosques and traditional spaces. Figure 3.1 describes the location of the study and the location of the Balai adat in the village.

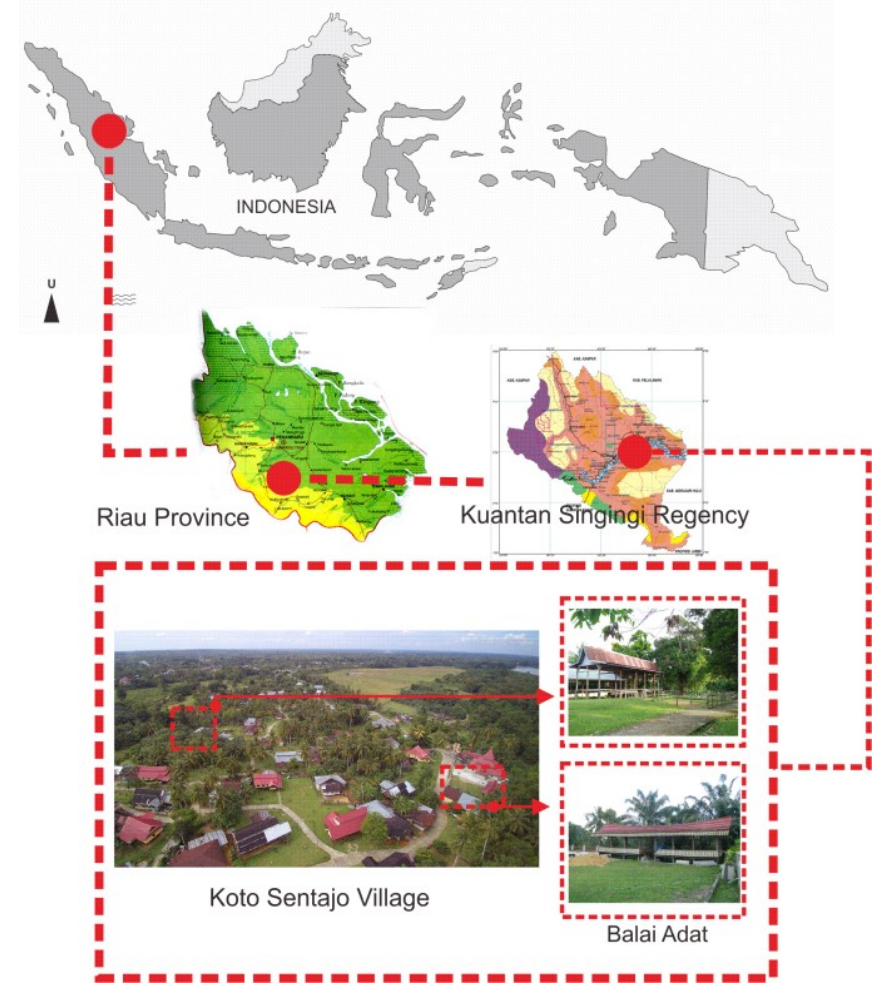

Figure 3.1 research sites

In Koto Sentajo village, there are traditional buildings for deliberation and are still preserved. the building is called a Balai adat. Balai adat is a traditional building that serves as a gathering place for deliberations by traditional stakeholders. Balai adat is used when there is an affair or problem within the village that must be negotiated together to find consensus results from several indigenous delegates from the tribe in Koto sentajo. 
In the Balai adat, there is a tabuah, a drum which functions as a sign that there is information on misfortune in a village. Tabuah is located at the top of the hall.
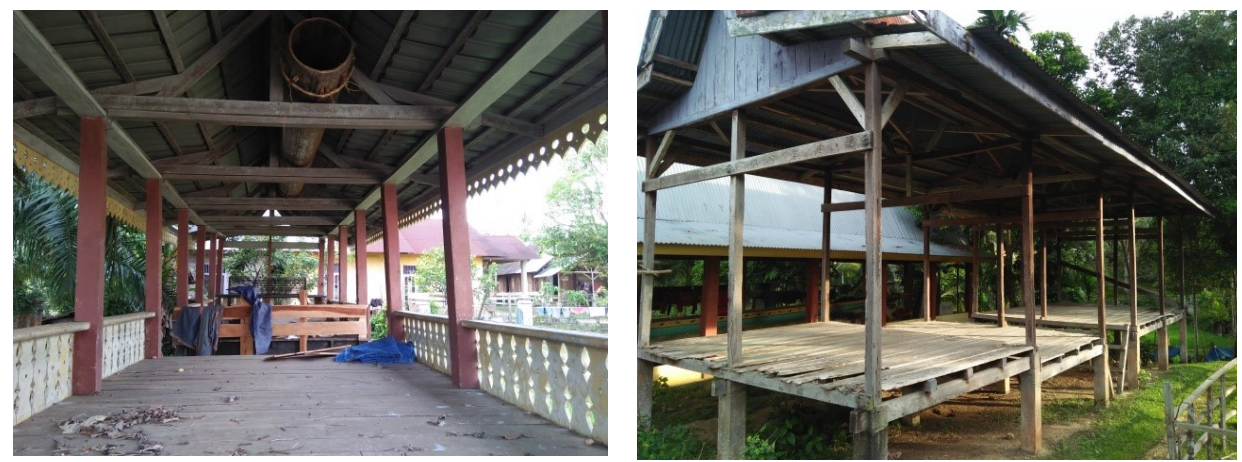

Figure 3.2 Balai Adat in Koto Sentajo Sources: Survey, 2019

In Koto Sentajo there are two Balai Adat. Balai Adat for customary events and Balai Adat for traditional silat. Balai Adat for customary events is a Balai adat located beside the mosque. The Balai adat was rebuilt in 1993 while maintaining the old form. The community has a term, Lapuak-Lapuak diganti, usang-usang di barui. Which means, if there is a weathered one then it is replaced, and if there is something obsolete, it is updated.

Balai adat for traditional silat is old and original. when silat show, the Balai adat functioned as a place to play traditional music.

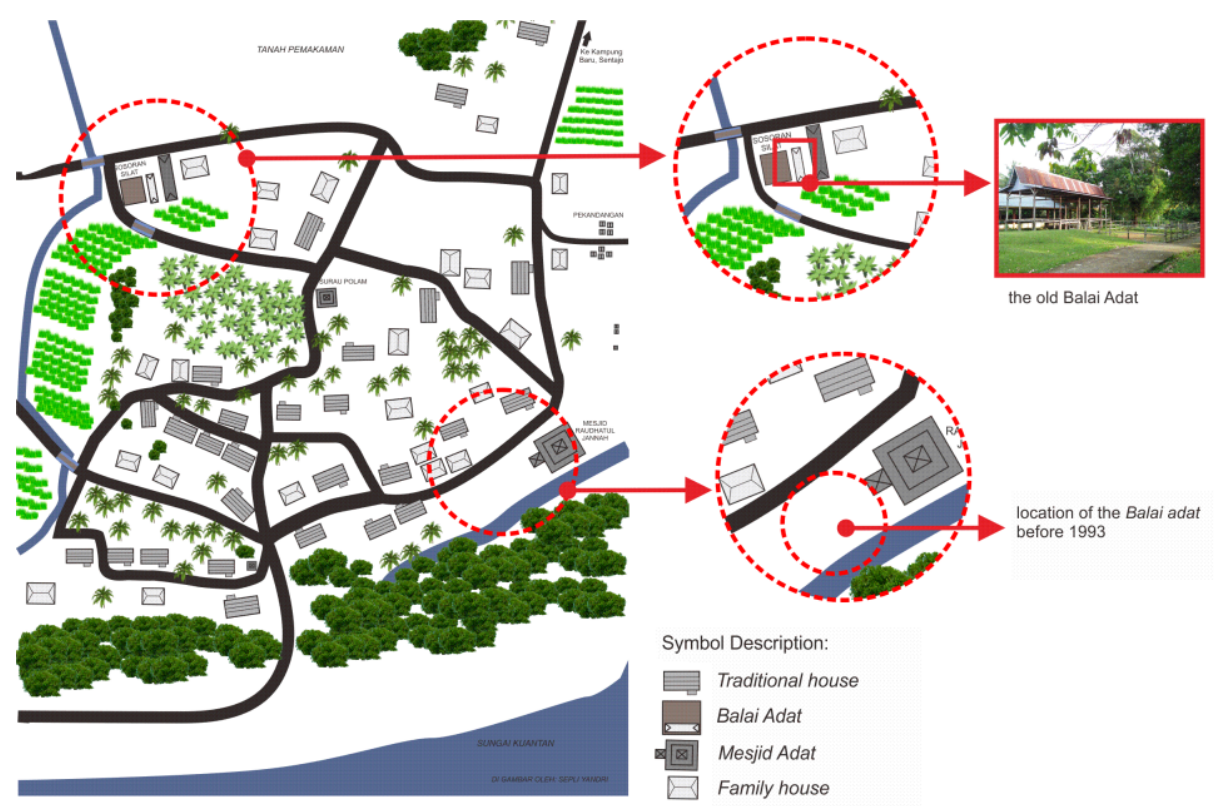

Figure 3.3. the location of the Balai Adat in Koto Sentajo before 1993 Sumber: Author Analysis, 2019 


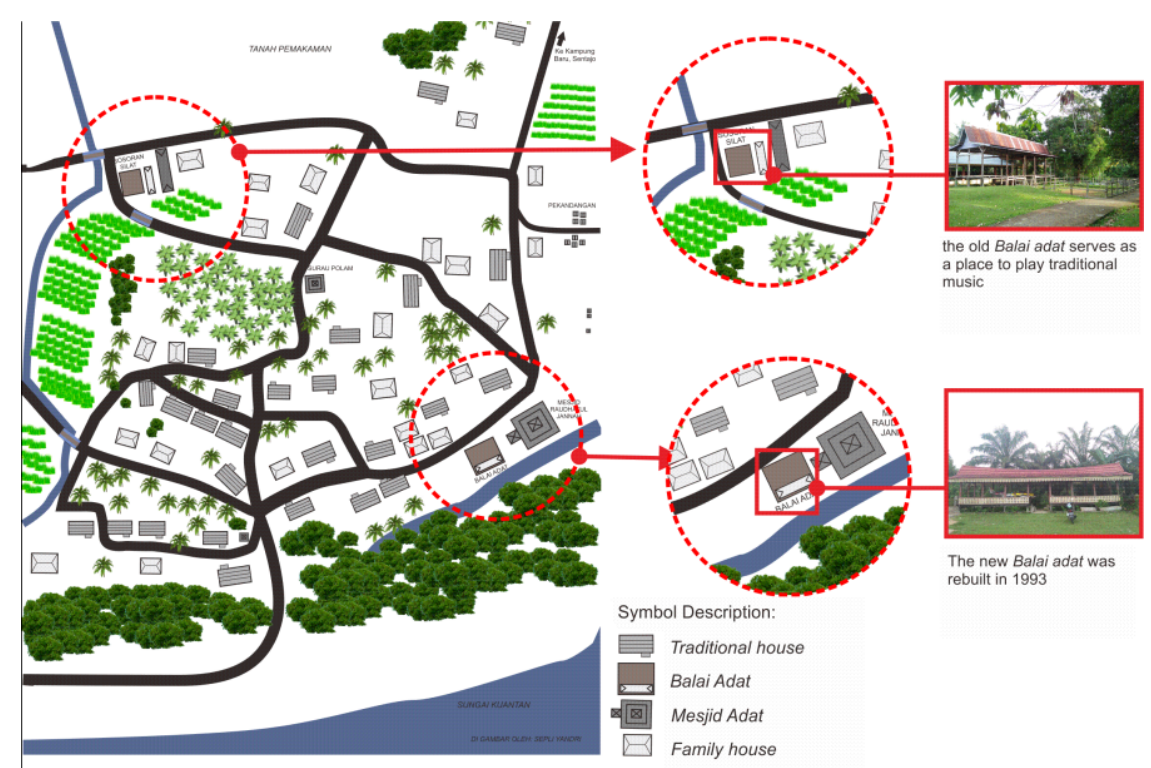

Figure 3.4. Location of Balai Adat in Koto Sentajo after being renewed Sumber: Author Analysis, 2019

Balai adat that has been renewed until now has become one of the traditional symbols in Kenegrian Sentajo, which used to be a place of deliberation for traditional stakeholders in Koto Sentajo, while the Balai adat for silat is still preserved as a place for traditional arts such as playing traditional musical instruments and always used as the accompaniment to silat.

\subsection{Spatial Planning}

The Balai Adat was made of two parts, the left, and the right. This section is a higher floor, this indicates that the traditional stakeholders such as Datuk, Dubalang, Malin, Tengganai, and Monti. While the lower room is where the nephews sit

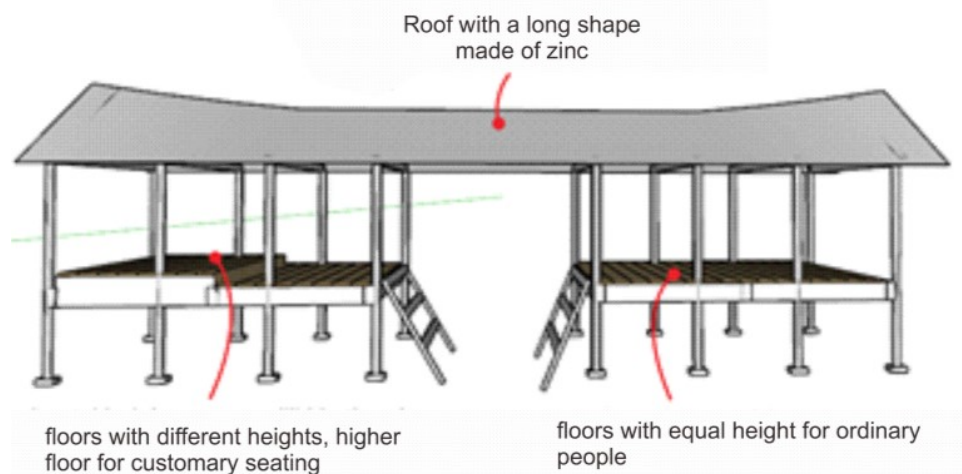

Figure 3.5: Balai Adat in the old Koto Sentajo that still applies different floor heights on each side

Sources: Author Analysis, 2019 


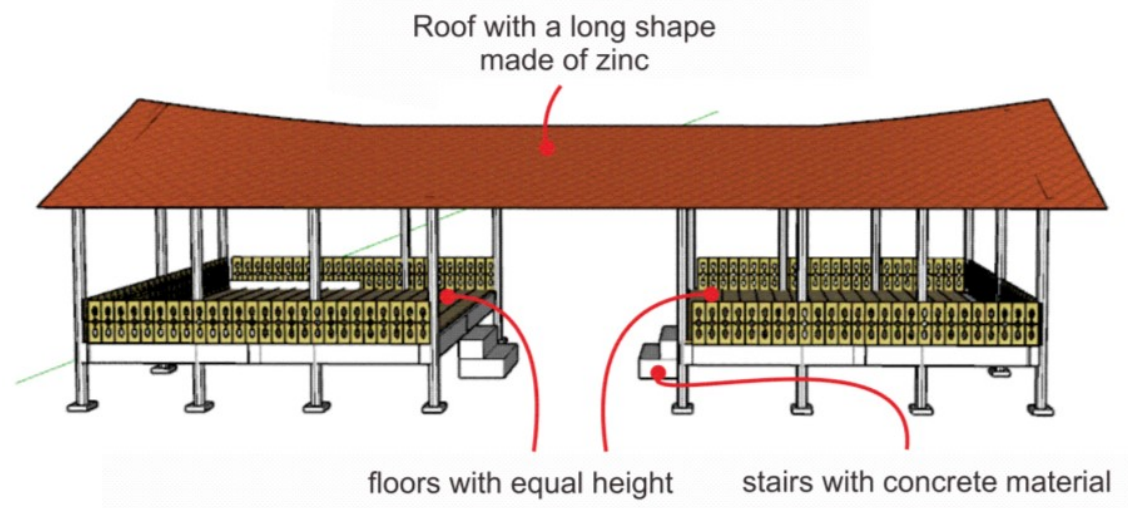

Figure 3.6: New Balai Adat in the Koto Sentajo with the same floor height on each side Sources: Author Analysis, 2019

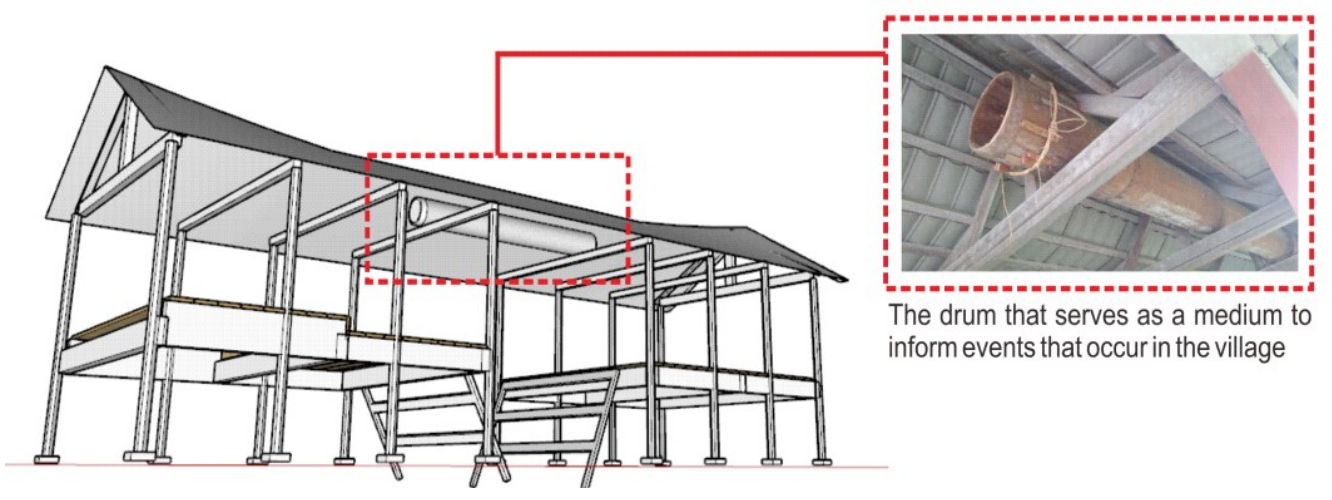

Figure 3.7: a drum in Balai Adat Sources: Author Analysis, 2019

\subsection{Spatial Function}

Balai adat is a traditional building that functions as a place for the traditional stakeholders to preach if something very important happens in the customary environment. For example, resolving the problem of one tribe member who violates customary norms, the solution will be negotiated and the determination of sanctions on the violating party is concluded in the Balai Adat. In the roof room, there is a beduk, which is a percussion which functions as a notification tool about important things that occur in people's lives, for example, death, and other important things. Aside from being a place for deliberation, the existence of a traditional hall is also a place for traditional music to be performed to parade silat which is routinely carried out by the community on Eid al-Fitr. 


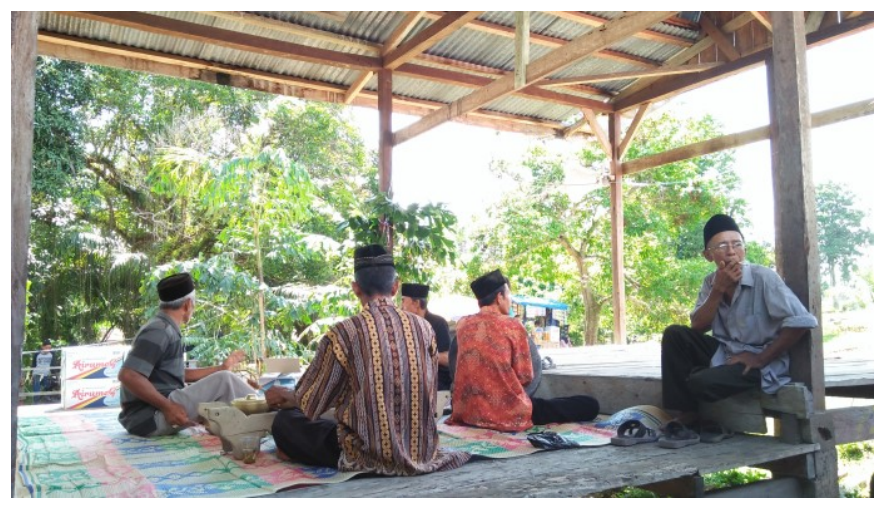

Figure 3.6: Another function of the Balai adat in Koto Sentajo as a place to play traditional music

Sources: survey, 2018

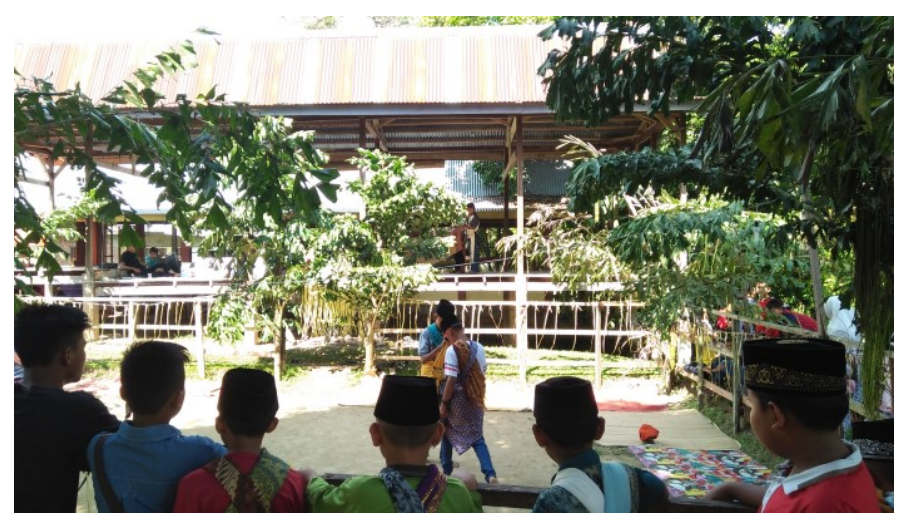

Figure 3.7: Balai adat which has a silat yard as a place for traditional silat performances

Sources: survey, 2018

\subsection{Construction and Shape}

The Balai adat building is a building with an elongated stage. The pillars of the building were made of wood. The floor and wall were made of wooden boards. The roof of was made of zinc roof. Just like the traditional house buildings in Koto sentajo, the pillars of the building stand on the pedestal foundation.

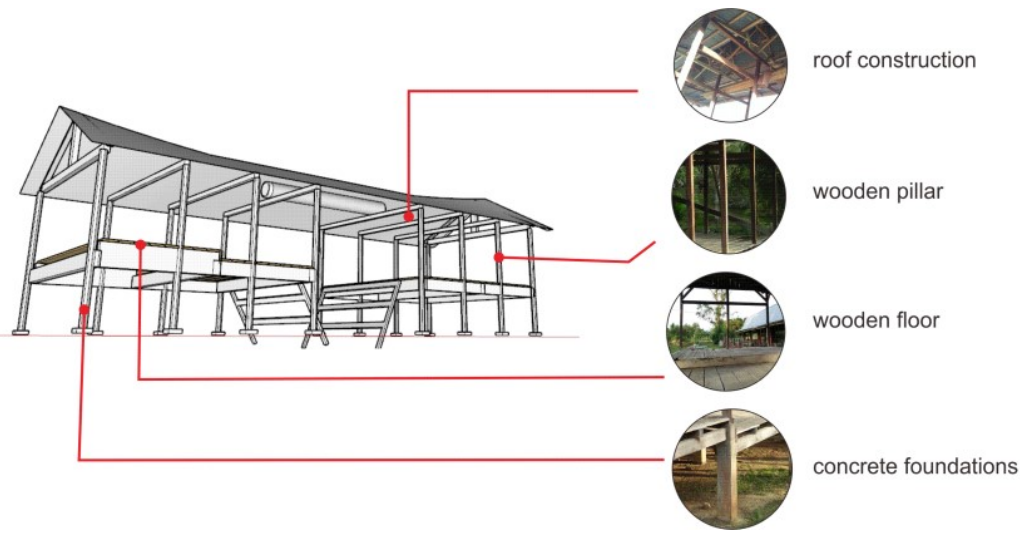

Figure 3.7: material and construction of Balai adat Sources: survey, 2018 


\section{Conclusion}

From the results of the analysis obtained through the interview process and seen directly in the Koto Sentajo village, can be concluded the roles and functions of the Balai Adat:

- Balai adat is a symbol of adat in the Koto Sentajo village as a link between adat and religion.

- $\quad$ Balai adat is used as a place for traditional stakeholder meetings

- Balai adat is a place of judgment

- Balai adat is a source of information in the village

- $\quad$ Balai Adat as a place to play traditional music to accompany traditional martial arts

The Balai Adat has a distinctive shape, long building with traditional construction. The Balai Adat is divided into two, the left side and the right side. The floor of Balai Adat has a different height. High floors for the traditional stakeholder. And lower floors for ordinary people.

\section{Acknowledgments}

We, as the authors, thank you and hope that the study in this journal can provide insight for readers. Thank you, we give specifically, to:

1. Mr. Ismet Rianto as Head of Gontiang Koto Sentajo Hamlet who gave research permission and gave an explanation regarding the research that we did.

2. To Mr. Madiyusman who was willing to provide information about life in Koto Sentajo.

3. All Koto Sentajo Villagers who have been willing to provide explanations related to the research we conducted.

\section{References}

Hamidy UU. (2000). Masyarakat Adat Kuantan Singingi. Uir Press. Pekanbaru

Muin, Maifadal. (2007). Adat persukuan daerah Kabupaten Kuantan Singingi Bagian 1. Dinas Kebudayaan Kesenian dan Pariwisata Kabupaten Kuantan Singingi. Teluk Kuantan

Rapoport, A. (1969) House Form and Culture. Prenrice Hall, Inc. Englewood Cliffs. New Jersey

Sumalyo, Yulianto. (1993). Arsitektur Kolonial Belanda di Indonesia. Yogyakarta: Gadjah Mada University Press.

Sasongko I .2005) Pembentukan Struktur Ruang Permukiman Berbasis Budaya ( Studi Kasus: Desa Puyung - Lombok Tengah). Jurnal Dimensi Teknik Arsitektur 33(1) :pg.1-8 